Reprod. Nutr. Develop., 1988, 28 (3 B), 819-820

\title{
Differential regulation of muscle and liver insulin receptors by energy restriction in growing rats
}

Michèle BALAGE, Michèle MANIN, M. ARNAL, J. GRIZARD

Laboratoire d'Etude du Métabolisme Azoté et C.N.R.S., UA 041123, I.N.R.A., Theix, 63122 Ceyrat, France.

Introduction. - Regulation of liver insulin receptors has been extensively studied in various physiopathological states such as diabetes, obesity and starvation (Czech, 1985). In contrast, muscle insulin receptors have only been poorly studied despite the fact that muscle is a major target organ for insulin. Some works demonstrated that skeletal muscle insulin receptors, like liver insulin receptors, could be down-regulated by plasma insulin levels (Brady et al., 1981). Other factors like muscle fiber types or circulating catecholamine levels could also intervene. The present study was carried out to compare variations of insulin receptors in skeletal muscle and liver in growing rats undergoing an energy restriction. The influence of plasma insulin was investigated.

Animals and treatments. - Male Sprague Dawley rats, housed in individual cages under controlled environmental conditions $\left(22{ }^{\circ} \mathrm{C}, 60 \%\right.$ relative humidity and 12 -hour dark period) were divided into 3 groups which received either a $12 \%$ protein diet (group $1:$ : control group ») or a $20 \%$ protein diet given in restricted amounts (groups 2 and 3 : "experimental groups»). The diets were given in six equal meals every 4 hours. The rats of experimental groups exhibited low carbohydrate and fat intakes (57 and $64 \%$ of group 1 respectively), resulting in a striking energy restriction. Intakes of proteins and other ingredients were the same in the 3 groups. The mean growth rate of rats in experimental groups 2 and 3 was significantly lower than in the control group ( $3 \mathrm{~g} / \mathrm{d} v s 6 \mathrm{~g} / \mathrm{d}$ respectively). In order to investigate the role of plasma insulin level on insulin receptors, the rats of group 3 were injected subcutaneously with lente $\mathrm{MC}$ Insulin (0.25-0.75 U/rat) every day at 12.00 . All the animals were killed in the 4 -hour period following the $15 \mathrm{hr}$-meal at a similar final body weight $(165 \mathrm{~g})$.

Plasma insulin was measured by direct radioimmunoassay. Livers and skeletal muscle (hind legs) were quickly removed and processed according to the standard methods of Neville (1968) and Kidwai et al. (1971) for liver and muscle plasma membrane preparations respectively, and the method of Havrankova, Roth and Browstein (1978) for microsomal membranes. Insulin binding was measured in intact plasma membranes and in Triton- $X 100$ soluble extracts (crude or wheat germ agglutinin purified) from microsomal membranes.

Results and discussion. - Peripheral plasma insulin was slightly decreased in rats from group 2 when compared to group 1 . The specific insulin binding was similar in skeletal muscles from rats of groups 1 and 2, whatever the receptor 
preparation. By contrast, there was an increase in the liver specific insulin binding in group 2 with highly purified plasma membranes $(+50-60 \%)$ and crude Triton $X 100$ solubilized membranes $(+25 \%)$. This result was in good agreement with the increased insulin binding to liver from diet-restricted rodents or fasted rats (Almira and Reddy, 1979). Despite a significant increase in insulinemia, insulin treatment (group 3 ) did not modify insulin binding to either muscle or liver receptor preparations as compared to group 2, suggesting that the moderate hypoinsulinemia of rats of group 2 might not be responsible for the increased insulin binding to liver.

Wheat germ agglutinin (WGA) purification of insulin receptors improved the apparent affinity of insulin binding sites in liver but not in muscle, suggesting the presence of a negative regulator of insulin binding affinity in the membrane (particularly in liver) which was removed by WGA purification. Such an hypothesis is supported by the work of Harmon et al. (1983) who characterized a membrane regulator of insulin receptor affinity. WGA purification of microsomal membranes did not reveal any difference in insulin binding to muscle between groups 1 and 2. Surprisingly, the increased insulin binding observed in crude liver receptor preparations from group 2 rats was not maintained to the same extent after purification. This suggests that the putative regulator of affinity might be involved in the difference in liver insulin binding between control and experimental rats; it would be less effective in experimental rats than in control.

In conc/usion, energy restriction of growing rats did not induce any change of muscle insulin receptors despite a $50 \%$ decrease in growth rate. In contrast, it increased insulin binding to liver.

Résumé. La régulation des récepteurs d'insuline dans le muscle et le foie a été étudiée chez le rat en croissance soumis à une restriction énergétique. La fixation d'insuline n'est pas modifiée dans le muscle, elle est au contraire augmentée dans les membranes plasmiques de foie et les préparations de membranes microsomales solubilisées au Triton $X 100$. Cette augmentation n'est pas maintenue totalement après purification des récepteurs par chromatographie d'affinité.

Almira E. C., Reddy W. J., 1979. Endocrinology, 104, 205-211.

Brady L. J., Goodman M. N., Kalish F. N., Ruderman N. B., 1981. Am. J. Physiol., 240, E184-E190. Czech M. P., 1985. Ann. Rev. Physiol., 47, 357-381.

Harmon J. T., Hedo J. A., Kahn C. R., 1983. J. biol. Chem., 258, 6675-6881.

Havrankova J., Roth J., Brownstein M. J., 1978. Nature (Lond.), 272, 827-829.

Kidwaï A. M., Radcliffe M. A., Duchon G., Daniel E. F., 1971. Biochem. biophys. Res. Commun., 45, $901-910$.

Neville M. D., 1968. Biochim. Biophys. Acta, 154, 540-552. 